\title{
BMJ Open Standard reference values of the postural control in healthy young female adults in Germany: an observational study
}

\author{
Daniela Ohlendorf, ${ }^{1,2}$ Charlotte Doerry, ${ }^{1}$ Vanessa Fisch, ${ }^{1}$ Sebastian Schamberger, ${ }^{3}$ \\ Christina Erbe, ${ }^{1}$ Eileen M Wanke, ${ }^{1}$ David A Groneberg ${ }^{1}$
}

To cite: Ohlendorf D, Doerry C, Fisch V, et al. Standard reference values of the postural control in healthy young female adults in Germany: an observational study. BMJ Open 2019;9:e026833. doi:10.1136/ bmjopen-2018-026833

- Prepublication history for this paper is available online. To view these files, please visit the journal online (http://dx.doi. org/10.1136/bmjopen-2018026833).

Received 21 September 2018 Revised 26 March 2019 Accepted 15 May 2019

\section{Check for updates}

(c) Author(s) (or their employer(s)) 2019. Re-use permitted under CC BY-NC. No commercial re-use. See rights and permissions. Published by BMJ.

${ }^{1}$ Institute of Occupational Medicine, Social Medicine and Environmental Medicine, Goethe University Frankfurt, Germany

${ }^{2}$ School of Dentistry, Department of Orthodontics, Goethe-

University Frankfurt, Germany

${ }^{3}$ Department for Orthodontics, University Medical Center of the Johannes Gutenberg University Mainz, Germany

Correspondence to

Dr Daniela Ohlendorf;

ohlendorf@med.uni-frankfurt.de

\section{ABSTRACT}

Objective Many people of all ages suffer from vertigo due to different reasons. The comparison of patient data with standard values can highlight deteriorations or changes in postural control and thus indicate, for example, an increased risk of falling. Our aim is to measure standard values for the postural control of young healthy women.

Design Observational study.

Setting Institute of Occupational Medicine, Social

Medicine and Environmental Medicine, Goethe-University Frankfurt/Main.

Participants 106 healthy German female subjects aged between 21 and 30 years ( $25 \pm 2.7$ years) were measured. Their average body mass index (BMI) was $21.1 \pm 2.61 \mathrm{~kg} /$ $\mathrm{m}^{2}$.

Outcome measures A pressure measuring platform was used to measure the weight distribution and postural sway in habitual standing. Median, tolerance range and $\mathrm{Cl}$ were calculated.

Results Height, weight and BMI are comparable to the average young German female population. The load distribution between right and left foot was 49.91\%:50.09\%. The forefoot was less loaded than the rear foot (33.3\%:66.67\%). The right rear foot carried most of the body weight (34.34\%). The average body sway was $9.50 \mathrm{~mm}$ in the frontal and $13.00 \mathrm{~mm}$ in the sagittal plane. Conclusions Standard values for the postural control of the women aged 21-30 years correlate with the already collected data of healthy subjects and can therefore be described as representative. The standard values enable diagnosing and treating impaired balance.

\section{INTRODUCTION}

Vertigo is a widespread disease. Nearly one-third of the global population experiences at least one severe dizziness attack during life across all ages. ${ }^{1}$ According to the "German publisher health information" every 10th patient reports regular dizziness. Moreover, every fifth adult frequently suffers from vertigo. Vertigo patients are often restricted in both, every day and professional activities, and are sometimes unable to work for months. ${ }^{2-4}$ The causes and their nature

\section{Strengths and limitations of this study}

Large number of healthy young female participants aged 21-30 years.

- Pressure measuring platform provides quantitative analysis of the postural control.

- Missing track of the fluctuation movements

- External influences (such as occupational environment) were not assessed which might influence the body posture.

of occurrence are many sided. The latter range from tumours and heart diseases to epilepsy, migraine and temporomandibular disorder (TMD). ${ }^{356}$ In terms of occurrence, a distinction must be made between objective (the environment is spinning around relative to oneself) and subjective vertigo (oneself is spinning around relative to the surrounding). An objective vertigo may occur due to diseases of the inner ear or disturbances of vestibular centres or pathways in the central nervous system. ${ }^{7}$ Dizziness is often described as a symptom of TMD. ${ }^{8-11}$ TMD comprises various deviations of the normal function of the temporomandibular system, whereas such patients often suffer from tooth, muscular, temporomandibular, ear, head or back pain as well as tinnitus apart from vertigo. TMD occurs due to different reasons: dentogenic, myogenic, psychogenic and arthrogenic causes are reported. ${ }^{911}$ Based on clinical experiences about $60 \%-70 \%$ of the general population have at least one sign of TMD. ${ }^{12}$ According to the National Institute of Dental and Craniofacial Research ${ }^{13}$ more than 10 million people in the USA suffer from TMD. Nowadays, about $20 \%$ of the population suffer from a TMD requiring treatment, while a third of people suffer from TMD-typical parafunctions. ${ }^{14}$ 
The fact that equilibrium disorders, like vertigo, can occur as a symptom of TMD, has already been described frequently in literature. ${ }^{8-11}{ }^{15}$ It has not been sufficiently investigated how the components of the sensorimotor system, which maintain the postural control, and the temporomandibular system interact exactly. ${ }^{16-20}$ In this context, different theories are stated for the explanation of possible interdependencies, such as stimulus propagation through fascial systems ${ }^{21}$ or muscle chains. ${ }^{22}{ }^{23}$ The role of the trigeminal nerve and a possible correspondence of its nuclei with the vestibular nuclei is also frequently discussed. ${ }^{162425}$

Even if no scientific explanations are definitely proven for the relationship of those different body structures, there is, however, a common basic idea to consider the human body as a unit. ${ }^{212627}$ This way postural control could be responsible for symptoms in anatomically distant parts of the body such as the temporomandibular system and also be affected by these body parts itself. In order to diagnose and treat pathologies of the weight distribution or the body sway at an early stage, posturographic standard values are essential. Unfortunately, such standard values can barely be found in literature. ${ }^{28}$ The test groups of the few existing studies were not homogeneous. ${ }^{28-30}$ The comparison of patient data with standard values could protect patients from worsening symptoms such as vertigo (objective) and thus prevent falls. Likewise, a possible incapacity to work could be prevented.

Therefore, the aim of the present study is to determine standard values for postural control in young, healthy women ${ }^{31}$ since gender-specific differences in pain threshold, hormonal balance and connective tissue have already been identified. ${ }^{32-34}$ Consequently, the focus on one gender-female sex-seems advisable. Since a deterioration of postural control with increasing age was already proven, ${ }^{3536}$ a young healthy test group between the ages of 21 and 30 was selected.
Methods

Subjects

As subjects 106 adult women aged between 21 and 30 years volunteered in this study All subjects criteria, like age, body mass index (BMI) (according to WHO criteria ${ }^{37}$ ), height, weight, handedness and angle-class, are listed in table 1 .

$72.6 \%$ of the participants were students. The remaining $27.4 \%$ belonged to various professional groups (eg, $\mathrm{PhD}$ students, physicians, dentists, dental assistants, nurses, office employees, teachers).

Subjects who reported severe pain, vertigo, TMD (clinical Temporo-mandibula joint (TMJ) exam), current illnesses or surgery within the last 2 years on spine, shoulders or pelvis were excluded from the study. Women who were currently in a physiotherapeutic or orthopaedic therapy, taking muscle relaxants or had ever been diagnosed with postural deficiencies were not accepted as participants. The participants were recruited in different ways, for example, via social networks or from the private environment.

\section{Patient and public involvement}

No patients were involved. All volunteers were healthy and informed about the study design before giving written informed consent.

\section{Measurement systems}

Posturography

The pressure measuring platform GP MultiSens (GeBioM GmbH, Münster, Germany) was used to measure the postural control with a measuring frequency of $100 \mathrm{~Hz}$ per sensor (total sampling rate of approximately $500 \mathrm{kHz}$ ). The measurement area is $38.5 \times 38.5 \mathrm{~cm}$, into which 2304 pressure sensors are integrated. The sensors are arranged in a matrix form and distributed at a density

Table 1 Patient characteristic including average age, age distribution, average BMI, BMI distribution according to WHO classification

\begin{tabular}{|c|c|c|c|c|c|}
\hline $\begin{array}{l}\text { Average age } \\
\text { (years) and age } \\
\text { distribution }\end{array}$ & $\begin{array}{l}\text { Average BMI } \\
\left(\mathrm{kg} / \mathrm{m}^{2}\right) / \\
\text { BMI distribution } \\
\text { according to } \\
\text { WHO classification }\end{array}$ & Average height & Average weight & Handedness & Angle-class \\
\hline $\begin{array}{l}25.05 \pm 2.68 \\
21 \text { years }=10 \\
22 \text { years }=9 \\
23 \text { years }=16 \\
24 \text { years }=13 \\
25 \text { years }=16 \\
26 \text { years }=10 \\
27 \text { years }=8 \\
28 \text { years }=9 \\
29 \text { years }=9 \\
30 \text { years }=6\end{array}$ & $\begin{array}{l}16.9-37.6 \mathrm{~kg} / \mathrm{m}^{2} \\
21.1 \pm 2.61 \\
\text { underweight: } 6.6 \%(\mathrm{n}=7) \\
\text { normal weight: } 87.7 \% \\
(\mathrm{n}=93) \\
\text { (pre)obese: } 5.7 \%(\mathrm{n}=6)\end{array}$ & $1.69 \pm 0.06 \mathrm{~m}$ & $60.3 \pm 7.9 \mathrm{~kg}$ & $\begin{array}{l}\text { Right-handed: } \\
95.3 \% \\
\text { Left-handed: } 4.7 \%\end{array}$ & $\begin{array}{l}\text { Angle-class I: } 41.5 \% \\
(\mathrm{n}=44) \\
\text { Angle-Class II: } 34 \% \\
\text { ( } n=36) \\
\text { Angle-Class III: } \\
24.5 \%(n=26)\end{array}$ \\
\hline
\end{tabular}

BMI, body mass index. 
of 1.5 sensors $/ \mathrm{cm}^{2}$. According to the manufacturer the maximum measurement error is $\pm 5 \%$.

\section{Examination procedure}

Each subject was instructed to stand within the circle depicted on the plate, in habitual body position, jaw in rest position and fixing a point at eye level without moving. The postural control was recorded for $30 \mathrm{~s}$ with a three-time measurement repetition. The following parameters were used for the statistical evaluation: (a) percentage distribution of the left/rightforefoot (\%), (b) percentage distribution of left/right rearfoot (\%), (c) percentage distribution of left/rightfoot, (d) percentage distribution of forefoot/rearfoot (\%), (e) maximum body sway in frontal direction $(\mathrm{mm})$, (f) maximum body sway in sagittal direction $(\mathrm{mm})$.

\section{Statistical evaluation}

The data were analysed using the statistics programme BiAS V.11.03 (Epsilon Verlag, Darmstadt, Germany). The data were first tested for normal distribution by the Kolmogoroff-Smirnov-Lilliefors test. Either parametrical tolerance regions or non-parametrical tolerance regions were calculated which were defined by the upper and lower limit for $95 \%$ of all values $(= \pm 2 \sigma$ values). These values have been found in about $95 \%$ of the examined subjects. Within this tolerance range all values have to be considered as normal so that the tolerance ranges estimate the central part of $95 \%$ of the value of the measured subject population. The two-sided $95 \%$ CI was calculated and indicates the possible range for the mean or median value depending on the distribution quality and shows the 'accuracy' of these values.

\section{RESULTS}

Table 2 contains mean values/medians, the tolerance range (lower and upper limit) and the $\mathrm{C}$ (left and right limits).
The left forefoot was loaded on average with $18.33 \%$ of the body weight with a tolerance range between $9.89 \%$ and $32.00 \%$ and a CI between $17.33 \%$ and $19.33 \%$. The right forefoot had on average the lowest percentage of the weight with $15.57 \%$. The tolerance range was between $5.22 \%$ and $25.92 \%$, the CI's left margin was $14.57 \%$ and the right margin was $16.57 \%$. The left rearfoot was loaded with an average of $31.36 \%$ with a tolerance range between $19.23 \%$ and $43.48 \%$ and the CI being between $30.19 \%$ and $32.53 \%$. The main body weight was carried by the right rearfoot: the mean value was $34.34 \%$, the lower limit of the tolerance range was $20.67 \%$, the upper limit was $48.01 \%$ and the left and right limits of the CI were $33.02 \%$ and $35.66 \%$.

The ratio of the load distribution between the right and left foot was $49.91 \%: 50.09 \%$ (figure 1A).

The forefoot was less loaded than the rearfoot, which carried $66.67 \%$ of the body weight (forefoot: $33.3 \%$; figure 1B). The body sway in frontal plane was $9.50 \mathrm{~mm}$ on average with the tolerance range being between 3.67 and $17.66 \mathrm{~mm}$, and the CI between 8.00 and $10.00 \mathrm{~mm}$. The tolerance range of the sway in sagittal plane was between 5.22 and $24.44 \mathrm{~mm}$ with the CI being between 12.00 and $14.33 \mathrm{~mm}$. The mean value of the sway in sagittal plane was $13.00 \mathrm{~mm}$.

\section{DISCUSSION}

The women examined in the present study were on average $169 \mathrm{~cm}$ tall, weighed $60.28 \mathrm{~kg}$ and had an average BMI of $21.1 \mathrm{~kg} / \mathrm{m}^{2}$. In comparison to other German surveys ${ }^{38} 39$ the present women are marginally taller, lighter and have a lower BMI, which could be lead back to the social status of the subjects, an above-average conscious diet or a high stress level among students (72.6\% of the participants). $41.5 \%$ of the subjects showed a neutral occlusion (AngleClass I) while $34 \%$ presented a distal and $24.5 \%$ a mesial occlusion (Angle-Class II/III). These subject criteria

Table 2 Plantar pressure distribution and body sway

\begin{tabular}{|c|c|c|c|c|c|}
\hline & Median & $\begin{array}{l}\text { Tolerance range- } \\
\text { lower limit }\end{array}$ & $\begin{array}{l}\text { Tolerance range- } \\
\text { upper limit }\end{array}$ & $\mathrm{Cl}$-left limit & $\mathrm{Cl}$-right limit \\
\hline Left forefoot (\%) & 18.33 & 9.89 & 32.00 & 17.33 & 19.33 \\
\hline Left rearfoot (\%) & 31.36 & 19.23 & 43.48 & 30.19 & 32.53 \\
\hline Right rearfoot (\%) & 34.34 & 20.67 & 48.01 & 33.02 & 35.66 \\
\hline Right foot (\%) & 49.91 & 35.81 & 64.02 & 48.55 & 51.28 \\
\hline Forefoot (\%) & 33.33 & 21.22 & 53.67 & 30.67 & 34.67 \\
\hline Rearfoot (\%) & 66.67 & 46.33 & 78.78 & 65.33 & 69.33 \\
\hline $\begin{array}{l}\text { Body sway in frontal } \\
\text { plane }(\mathrm{mm})\end{array}$ & 9.50 & 3.67 & 17.66 & 8.00 & 10.00 \\
\hline
\end{tabular}



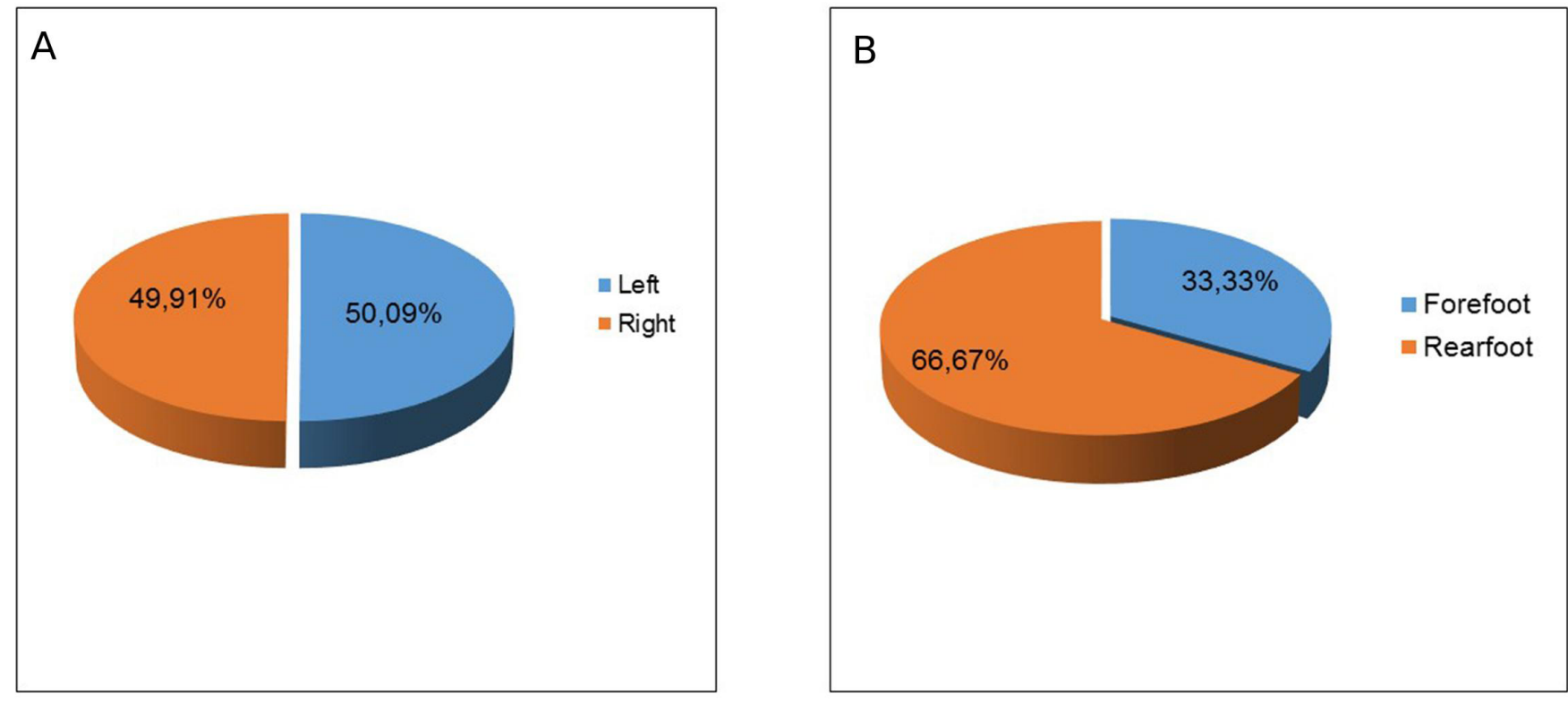

Figure 1 Average percentage load distribution of the right/left foot and forefoot-rearfoot distribution. (A) Average percentage load distribution on the right and left foot. (B) Average percentage load distribution on the forefoot and rear foot.

enable the conclusion that these women are representative for this age-specific German population and therefore suitable to be taken as an experimental group.

The postural mean values for the load distribution were almost balanced with a left-right ratio of $49.91 \%$ (left foot): $50.09 \%$ (right foot). For the forefoot and rear foot distribution a ratio of $33.33 \%$ : $66.67 \%$ can be calculated. The mean body sway was $9.5 \mathrm{~mm}$ in mediolateral and $13.0 \mathrm{~mm}$ in anterior-posterior direction. The equilibrium of the participants can therefore be described as quite balanced regarding the load on the left/rightfoot, while an increased shift in weight on the rear foot, especially the right rear foot, can be observed.

Compared with our subjects, men with identical age and sample size show greater body sway in mediolateral $(11.67 \mathrm{~mm})$ and anterior-posterior $(17.67 \mathrm{~mm})$ direction by using the same measuring platform. ${ }^{40}$ Furthermore, this male subjects had a left-right foot ratio of 56\%:44\% and a forefoot-rearfoot ratio of 37\%:63\% with the most load on the left rear foot. Accordingly, men fluctuate more strongly with having more weight load on the left rear foot. The overall significantly higher load on the rear foot can be explained by the position of the body's centre of gravity. Since it is located in front of the promontory, the ankle joints and thus the posterior section of the feet are located on the imaginary line of the centre of gravity. ${ }^{41}$

According to Obens ${ }^{42}$ a 50\%:50\% weight distribution between the right and the left foot in healthy subjects is ideal when standing upright, whereas a forefoot/rear foot ratio of $33 \%$ to $66 \%$ is normal. Lalande et at $t^{43}$ supported this result. Furthermore, Burini et a $l^{36}$ confirmed our results since they evaluated postural standard values in healthy volunteers of different age groups. For the age group 20-29 ( $\mathrm{n}=29$; 11 female) similar average values were found with $7 \mathrm{~mm}$ for the body sway in mediolateral and $14 \mathrm{~mm}$ in anterior-posterior direction while higher deflections were measured for older subjects. Rauch et $a l^{35}$ Burini et $a l^{36}$ and Lalande $e t a t^{33}$ stated that with increasing age the body sway decreased, which is explained by the loss of different stimuli detecting and forwarding structures in the inner ear such as the hair cells in the vestibular organ and the neurons in the vestibular ganglion. ${ }^{44-48}$ The low body sway in the present study can be explained by the young age of the subjects. Since age-related changes in postural control have already been proven $^{35} 3643$ and data for gender-specific differences are scarce, further research should be conducted into this topic with regard to standard values. Especially in diseases with objective vertigo a comparison of individual measurements with standard values could allow a rapid evaluation of the therapeutic efficiency of treatment.

As the present values for left-right and forefoot-rearfoot weight distribution in healthy women are very similar to the results of other studies, the standard values appear to be gender-independent. However, one fact that has not yet been described in the literature, is a varying level of side-related rear foot loading between the genders. Between men $^{40}$ and women in the second age decade, there is a difference in rear foot percentage load. For men the left and for women the right rear foot bear the highest percentage load. Since it can be assumed that the majority of women regularly carry handbags, the deviation of female equilibrium could be attributed to this habit, as shown by Son et al. ${ }^{49}$ They concluded that the temporary one-sided wear does not correlate with the gait, while the habit of carrying a handbag always on the same arm (right or left) affects the parameters step length, step width, foot position and speed. This is explained by an asymmetrical load caused by the handbag which leads to a deviation of the centre of pressure (COP). This in 
turn results in an adaptation of the body to maintain the balance, which causes postural changes of the trunk and the extremities. Furthermore, this leads to an increased ground reaction force in the ipsilateral foot, which then causes a locally amplified muscle force. ${ }^{49}$ This gender difference was neither found by Tuna et $a l^{\tilde{p}^{0}}$ between the load on the right and left foot in boys and girls, nor by Lalande $e t a t^{33}$ in adults as they have not analysed this in more detail.

Another possibility for the higher load on the right rear foot could be due to the handedness of the subjects. 95\% of the 106 subjects were right-handed and only $5 \%$ left-handed. When looking at the load on the right or left (rear) foot, it is noticeable that the right-handed participants put more pressure on the right (rear) foot than on the left (rear) foot. The reverse effect could be observed in the left-handed women. Since the number of lefthanders with $n=5$ was extremely small, the validity of this comparison is however very low. Moreover, it is conceivable that not only the handedness, but also the side of the dominant $\mathrm{leg}^{51}$ or of the preferred chewing side, ${ }^{52-55}$ has an influence on posture and postural control. Since such influencing variables have not been considered in previous investigations, this assumption is purely hypothetical in nature with regard to postural standard values. TMD or vertigo could also be another possible influencing factor on postural control, which needs to be clarified. Appropriate analyses for determination of these components should be used in further studies of the same topic.

In view of the limiting factors of this examination, the question arises whether a pressure measuring platform is at all a suitable measuring system for determining standard values. Here, Perinetti $e$ t $a \tilde{p}^{6}$ confirm an acceptable reliability for the sway area and velocity, but recommend to include a threshold of $25 \%$, if at least two different conditions are to be compared with each other. Intersession reliability was also proven by Baldini et $a e^{\tilde{p}^{7}}$ For the 'S-Plate', a pressure measuring platform similar to the one used here with a larger sensor size and smaller number of sensors, good reliability and reproducibility could be observed. ${ }^{58}$ Consequently, the pressure platform is suitable to represent postural standard values, but it must be considered that the sensors are temperature-sensitive. For this reason, the measurements were always carried out in the same room under constant conditions. ${ }^{59}$ However, external influences (such as occupational environment) which might influence the body posture were not assessed. The software should additionally give information about the COP data, that is, information about its ellipse (width and height) or which direction of body sway (anterior-posterior or mediolateral) is predominantly present, which the present software does not supply. This could lead to more precise statements, which could possibly help in the analysis of the vertigo. Also extending this approach to different age groups would allow a generalisation of our results.

\section{CONCLUSIONS}

The standard values for the postural control of the women aged 21-30 years correlate with the few already collected data of healthy subjects ${ }^{404360}$ and can therefore be described as representative. The equilibrium of the participants could be described as quite balanced regarding the load on the left/rightfoot, while an increased shift in weight on the rear foot could be observed considering the forefoot/rearfoot load distribution. It could be detected that the major percentage of body weight lies on the right rear foot in young women. The mean body sway was lower in the frontal plane than in the sagittal plane. In future, these standard values could be used to objectively evaluate a treatment outcome in patients with relevant diseases, for example, inner ear disturbances.

Contributors DO, CD, VF, SS, CE, EMW and DAG made substantial contributions to the conception and design of the manuscript, DO, CD and VF made substantial contributions to the construction of the measurement protocol and DO has been involved in the statistical data analysis. All authors have read and approved the final manuscript.

Funding The authors have not declared a specific grant for this research from any funding agency in the public, commercial or not-for-profit sectors.

Competing interests None declared.

Patient consent for publication Not required.

Ethics approval A positive ethics recommendation from the Department of Medicine of the Goethe University Frankfurt am Main (ethic number: 103/16) was obtained.

Provenance and peer review Not commissioned; externally peer reviewed.

\section{Data sharing statement There are no additional data.}

Open access This is an open access article distributed in accordance with the Creative Commons Attribution Non Commercial (CC BY-NC 4.0) license, which permits others to distribute, remix, adapt, build upon this work non-commercially, and license their derivative works on different terms, provided the original work is properly cited, appropriate credit is given, any changes made indicated, and the use is non-commercial. See: http://creativecommons.org/licenses/by-nc/4.0/.

\section{REFERENCES}

1. leadingmedicine guide. Schwindel - Medizinische Experten. 2017 http://www.leading-medicine-guide.de/Kopf-Hals-Augen/Schwindel (Accessed 03 Dec 2017).

2. Albathi M, Agrawal Y. Vestibular vertigo is associated with abnormal sleep duration. J Vestib Res 2017;27(2-3):127-35.

3. Wojtczak R, Narożny W, Kuczkowski J, et al. Epidemiology of dizziness in northern Poland - The first Polish neurootologic survey of the general population. Ann Agric Environ Med 2017;24:502-6.

4. Muncie HL, Sirmans SM, James E. Dizziness: Approach to Evaluation and Management. Am Fam Physician 2017;95:154-62.

5. Foley RW, Shirazi S, Maweni RM, et al. Signs and Symptoms of Acoustic Neuroma at Initial Presentation: An Exploratory Analysis. Cureus 2017;9:e1846.

6. Udagatti VD, Dinesh Kumar R. Migraine Related Vertigo. Indian J Otolaryngol Head Neck Surg 2017;69:563-7.

7. Post RE, Dickerson LM. Dizziness: a diagnostic approach. Am Fam Physician 2010;82(4):369-361.

8. Song HS, Shin JS, Lee J, et al. Association between temporomandibular disorders, chronic diseases, and ophthalmologic and otolaryngologic disorders in Korean adults: A cross-sectional study. PLoS One 2018;13:e0191336.

9. Keersmaekers K, De Boever JA, Van Den Berghe L. Otalgia in patients with temporomandibular joint disorders. J Prosthet Dent 1996;75:72-6.

10. Blakley BW, Goebel J. The meaning of the word "vertigo". Otolaryngol Head Neck Surg 2001;125:147-50.

11. Chole RA, Parker WS. Tinnitus and vertigo in patients with temporomandibular disorder. Arch Otolaryngol Head Neck Surg 1992;118:817-21. 
12. Dimitroulis G. Temporomandibular disorders: a clinical update. $B M J$ 1998;317:190-4.

13. National Institute of Dental and Craniofacial Research. TMJ (Temporomandibular Joint and Muscle Disorders). $2017 \mathrm{https}: / / \mathrm{www}$. nidcr.nih.gov/oralhealth/Topics/TMJ/TMJDisorders.htm (Accessed 03 Dec 2017).

14. GZFA. CMD-Statistik - Verbreitung der Craniomandibulären Dysfunktion. 2017 https://www.gzfa.de/diagnostik-therapie/cmdcraniomandibulaere-dysfunktion/cmd-symptome/cmd-statistik/ (Accessed 03 Dec 2017).

15. Nota A, Tecco S, Ehsani S, et al. Postural stability in subjects with temporomandibular disorders and healthy controls: A comparative assessment. J Electromyogr Kinesiol 2017;37:21-4.

16. Gangloff P, Perrin PP. Unilateral trigeminal anaesthesia modifies postural control in human subjects. Neurosci Lett 2002;330:179-82.

17. Bracco P, Deregibus A, Piscetta R. Effects of different jaw relations on postural stability in human subjects. Neurosci Lett 2004;356:228-30.

18. Perinetti G, Contardo L. Posturography as a diagnostic aid in dentistry: a systematic review. J Oral Rehabil 2009;36:922-36.

19. Cuccia AM. Interrelationships between dental occlusion and plantar arch. J Bodyw Mov Ther 2011;15:242-50.

20. Manfredini D, Castroflorio T, Perinetti G, et al. Dental occlusion, body posture and temporomandibular disorders: where we are now and where we are heading for. J Oral Rehabil 2012;39:463-71.

21. Myers TW. Anatomy Trains: Myofasziale Leitbahnen (für Manualund Bewegungstherapeuten). München: Elsevier Health Sciences Germany, 2015.

22. Ahonen J. Sportmedizin und Trainings/ehre. Stuttgart: Schattauer, 2008.

23. Ohlendorf D, Parey K, Kemper S, et al. Can experimentally induced alterations to occlusion influence human equilibrium? Manuelle Medizin 2008;46:412-7.

24. Buisseret-Delmas C, Compoint C, Delfini C, et al. Organisation of reciprocal connections between trigeminal and vestibular nuclei in the rat. J Comp Neurol 1999;409:153-68.

25. Pinganaud G, Bourcier F, Buisseret-Delmas C, et al. Primary trigeminal afferents to the vestibular nuclei in the rat: existence of a collateral projection to the vestibulo-cerebellum. Neurosci Lett 1999;264(1-3):133-6.

26. Korbmacher H, Eggers-Stroeder G, Koch L, et al. Correlations between dentition anomalies and diseases of the of the postural and movement apparatus--a literature review. J Orofac Orthop 2004;65:190-203.

27. Perinetti G, Primozic J, Manfredini D, et al. The diagnostic potential of static body-sway recording in orthodontics: a systematic review. Eur J Orthod 2013;35:696-705.

28. Pomarino D, Nawrath A, Beyer J. Altersabhängige Messungen zur posturalen Stabilität gesunder Probanden, 2013.

29. Moghadam M, Ashayeri $\mathrm{H}$, Salavati M, et al. Reliability of center of pressure measures of postural stability in healthy older adults: effects of postural task difficulty and cognitive load. Gait Posture 2011;33:651-5

30. Lin D, Seol H, Nussbaum MA, et al. Reliability of COP-based postural sway measures and age-related differences. Gait Posture 2008;28:337-42.

31. Ohlendorf D, Mickel C, Filmann N, et al. Standard values of the upper body posture and postural control: a study protocol. J Occup Med Toxicol 2016;11:34.

32. Abubaker AO, Raslan WF, Sotereanos GC. Estrogen and progesterone receptors in temporomandibular joint discs of symptomatic and asymptomatic persons: a preliminary study. J Oral Maxillofac Surg 1993;51:1096-100.

33. Bush FM, Harkins SW, Harrington WG, et al. Analysis of gender effects on pain perception and symptom presentation in temporomandibular pain. Pain 1993;53:73-80.

34. Conti PC, Ferreira PM, Pegoraro LF, et al. A cross-sectional study of prevalence and etiology of signs and symptoms of temporomandibular disorders in high school and university students. J Orofac Pain 1996;10:254-62.
35. Rauch SD, Velazquez-Villaseñor L, Dimitri PS, et al. Decreasing hair cell counts in aging humans. Ann N Y Acad Sci 2001;942:220-7.

36. Burini A, de Bruin ED, Murer K. Erheben von Normdaten der Körperhaltungsvariablen für den zukünftigen Vergleich mit Schwindelpatienten, 2008.

37. Organization WH. Obesity: preventing and managing the global epidemic. Genf: World Health Organization, 2000.

38. Mensink G, Schienkiewitz A, Haftenberger M, et al. Übergewicht und Adipositas in Deutschland - Ergebnisse der Studie zur Gesundheit Erwachsener in Deutschland (DEGS1. 2013 http:// edoc.rki.de/docviews/abstract.php?id=2961 (accessed $03 \mathrm{Dec}$ 2017).

39. GE sundheit. Statistisches Bundesamt. 2017 https://www.destatis. de/DE/Publikationen/Thematisch/Gesundheit/Gesundheitszustand/ Koerpermasse5239003099004.pdf?_blob=publicationFile ((access: 03.12.17)).

40. Scharnweber B, Adjami F, Schuster G, et al. Influence of dental occlusion on postural control and plantar pressure distribution. Cranio 2017;35:358-66.

41. Drake R, Vogl AW, Mitchell AWM. Gray's Anatomy for Students E-Book. Elsevier Health Sciences 2009.

42. Obens T. Belastungs- / Druckverteilung unter dem Fuß in Statik und Dynamik.

43. Lalande X, Vie B, Weber JP, et al. Normal Values of Pressures and Foot Areas Measured in the Static Condition. J Am Podiatr Med Assoc 2016;106:265-72.

44. Rosenhall U, Rubin W. Degenerative changes in the human vestibular sensory epithelia. Acta Otolaryngol 1975;79(1-2):67-80.

45. Engström H, Ades HW, Engström B, et al. Structural changes in the vestibular epithelia in elderly monkeys and humans. Adv Otorhinolaryngol 1977;22:93-110.

46. Richter E. Quantitative study of human Scarpa's ganglion and vestibular sensory epithelia. Acta Otolaryngol 1980;90(3-4):199-208.

47. Campos A, Cañizares FJ, Sánchez-Quevedo MC, et al. Otoconial degeneration in the aged utricle and saccule. Adv Otorhinolaryngol 1990;45:143-53.

48. Anniko M. The aging vestibular hair cell. American journal of otolaryngology. May 1983;4:151-60.

49. Son S, Noh H. Gait changes caused by the habits and methods of carrying a handbag. J Phys Ther Sci 2013;25:969-71.

50. Tuna H, Yildiz M, Celtik C, et al. [Static and dynamic plantar pressure measurements in adolescents]. Acta Orthop Traumatol Turc 2004;38:200-5.

51. Fischer K. Rechts-Links-Probleme in Sport und Training: Studien zur angewandten Lateralitätsforschung. Schorndorf: Hofmann 1988.

52. Paphangkorakit J, Chaiyapanya N, Sriladlao P, et al. Determination of chewing efficiency using muscle work. Arch Oral Biol 2008;53:533-7.

53. Martinez-Gomis J, Lujan-Climent M, Palau S, et al. Relationship between chewing side preference and handedness and lateral asymmetry of peripheral factors. Arch Oral Biol 2009;54:101-7.

54. Ratnasari A, Hasegawa K, Oki K, et al. Manifestation of preferred chewing side for hard food on TMJ disc displacement side. J Oral Rehabil 2011;38:12-17.

55. Saccucci M, Tettamanti L, Mummolo S, et al. Scoliosis and dental occlusion: a review of the literature. Scoliosis 2011;6:15.

56. Perinetti G, Marsi L, Castaldo A, et al. Is postural platform suited to study correlations between the masticatory system and body posture? A study of repeatability and a meta-analysis of reported variations. Prog Orthod 2012;13:273-80.

57. Baldini A, Nota A, Assi V, et al. Intersession reliability of a posturostabilometric test, using a force platform. J Electromyogr Kinesiol 2013;23:1474-9.

58. Izquierdo-Renau M, Pérez-Soriano P, Ribas-García V, et al. Intra and intersession repeatability and reliability of the S-Plate ${ }^{\circledR}$ pressure platform. Gait Posture 2017;52:224-6.

59. Natrup J. Wie erfahre ich wenn es dem Fuß zu viel wird? OST. , 1999:11, 29-35.

60. Kim K, Kim CJ, Oh DW. Effect of backpack position on foot weight distribution of school-aged children. J Phys Ther Sci 2015;27:747-9. 